ISSN: 2362-1303 (Paper) | eISSN: 2362-1311(Online)

JOURNAL OF ADVANCED ACADEMIC RESEARCH (JAAR)

July 2015

\title{
Renewable Energy Enterprises in Nepal: Growth and Development
}

\author{
Maheshwar Prasad Yadav ${ }^{1} \&$ Prof. Dr. Radhe S. Pradhan ${ }^{2}$ \\ ${ }^{1} \mathrm{PhD}$ Scholar, Department of Management, Mewar University, Rajasthan, India \\ ${ }^{2}$ Professor, Tribhuvan University, Kathmandu, Nepal
}

Corresponding Author:

Maheshwar Prasad Yadav

mpyadav2006@gmail.com

\section{ABSTRACT}

Nepal has enormous potential for different kinds of renewable energies; however, biogas, solar and micro-hydro energies are only selected for this study. The study aims at determining growth and development of renewable energy sector and its relationship with renewable energy enterprises in Nepal. This study is based on secondary data covering a period of 37 years of biogas sector, 20 years of solar sector and 50 years of micro-hydro sector. Frequency table, percentage, graph, growth rate and correlation coefficient are employed to analyze the data. The study reveals the largest number of renewable energy enterprises is located in central development region (62.69\%) while it is least in farwestern region (3.08\%) of Nepal. The average growth of biogas, solar and micro-hydro construction companies are $7.96 \%, 21.18 \%$ and $16.07 \%$ respectively. The high penetration of biogas plants is in western region while solar home systems are in mid-western region. The highest number of micro-hydro schemes' installation in term of number and capacity are in eastern and western development region respectively. The result shows that biogas and solar sectors are growing in decreasing trend while micro-hydro sector has ups-down trend. There is significant positive relationship of renewable energy sector with renewable energy enterprises. The study concludes that the growth and development of the renewable energy sector plays a vital role in growth and development of renewable energy enterprises in Nepal. The paper can be extended through investigating characteristics of renewable energy enterprises and renewable energy entrepreneurs to get a greater insight into the results.

\section{KEY WORDS}

Biogas, Micro-hydro, Renewable Energy Enterprises, Solar

\section{INTRODUCTION}

Energy plays indispensable role in running the wheels of the economy of any country and more importantly in the lives and livelihoods of its people. Energy is necessary for daily survival (World Commission on Environment and Development, 1987). Energy is an essential ingredient of socio economic development and economic growth (Goldemberg, 1996). Additionally, energy is a vital input for many everyday activities like cooking, heating, lighting, etc. Energy is catalyst for economic development that leads to entrepreneurship development. 
ISSN: 2362-1303 (Paper) | eISSN: 2362-1311(Online)

JOURNAL OF ADVANCED ACADEMIC RESEARCH (JAAR)

July 2015

Nepal has over a half century history of promoting renewable energies. Renewable energy is energy that comes from resources which are continually replenished such as sunlight, wind, rain, tides, waves, and geothermal heat (Wikipedia: 28 Feb 2013). Non-renewable energy is energy that comes from resources which are not continually replenished such as coal, petroleum fuels and fuel wood etc. Those non-renewable sources of energy are also taken as traditional sources of energy. The use of renewable energy can reduce the dependency on traditional sources of energy. In such circumstances, Nepal has very high potential to exploit the renewable energy; however, it has not been exploited to the fullest. The energy sector of Nepal is characterized by a very heavy reliance on traditional resources that contribute to more than 85 percent of the total energy consumption (AEPC, 2012, p. 1). The use of Renewable Energy Technologies can reduce the dependency on traditional energy and help in protecting the environment and reduction of emission of greenhouse gases, contribute sustainable development, regional balance and increases the economic activities. It ultimately contributes to improve the health and educational status of the population as well (AEPC, 2012, p. 1). With above-mentioned backcloth, renewable energy can be the backbone of developing economies like Nepal.

The history of promoting domestic biogas is very long- over a half century. Over 299,338 biogas plants were installed throughout the country by mid July 2013. There are 109 biogas companies working in the sector to construct biogas plants throughout the country. In order to expedite the progress rate towards achieving the biogas potential of Nepal, Biogas Support Program was launched in 1992. Biogas Program came under the umbrella of Alternative Energy Promotion Center (AEPC) in 1996 (AEPC, 2014). As the result, biogas plant installation was rapidly increased after the end of nineties. Likewise, Yadav (2012) reveals the significant role of biogas for sustainable development in Nepal. Another study by Adhikary (2012) deals with green economy in pursuance of sustainable development and nature for an improved and sustained quality of life. Moreover, a study by Karki, Shrestha, Bajgain, \& Sharma (2009) reveals that the role biogas for national development along with the role of loan and subsidy in biogas development in Nepal. With above-mentioned scenarios, biogas sector has been growing considerably.

Furthermore, solar energy can be seen as a more reliable source of energy in Nepal than the traditional electricity. Private installations of solar panels are more frequent in Nepal. Solar energy is radiant light and heat from the sun harnessed using a range of ever-evolving technologies such as solar heating, solar photovoltaic, solar thermal energy, solar architecture and artificial photosynthesis (International Energy Agency, 2011). It is an important source of renewable energy. Nepal has over 421,728 solar home systems installed throughout the country by mid July 2013 with the total capacity of 10,461,799 WP. There are 97 solar companies working in the sector. A large number of people have gotten employment directly, indirectly in this sector. As the demand for solar is increasing, employment of skilled and unskilled labor Vol. 2. No. II

www.phdcentre.edu.np 
ISSN: 2362-1303 (Paper) | eISSN: 2362-1311(Online)

JOURNAL OF ADVANCED ACADEMIC RESEARCH (JAAR)

July 2015

has been increasing every year. Consequently, the potential of the solar development to create employment and enterprise development has already been demonstrated. Solar energy plays vital role in providing reliable energy. Additionally, Yadav (2015) finds the number of solar home systems and its capacity installed has significant impact on enterprise development. The growth and development of solar sector is important in developing solar companies.

The micro-hydro electrification scheme was installed in 1962. Nepal has over 3,096 microhydro electrification schemes installed throughout the country by mid July 2013 with its capacity of 47,884 kW. There are 78 micro-hydro construction companies working in the sector. Pico, micro and mini hydro electrification schemes are considered as micro-hydro electrification schemes in this study. Pico-hydro shall be understood as hydroelectric generating units with capacities up to $10 \mathrm{KW}$ (AEPC, 2013). Micro-hydro power scheme is hydroelectric generating units with capacities ranging above 10 to $100 \mathrm{KW}$ (AEPC, 2013). Moreover, minihydro power scheme is the hydropower system that generates electric power from $100 \mathrm{KW}$ to $10 \mathrm{MW}$ and serves nearby households through a mini-grid (AEPC, 2013). Pokharel (2006) relates micro-hydro technology with creating enterprises and sustainable development. The micro-hydro sector is important ingredients of renewable energy sector in Nepal.

Despite all these facts and empirical evidences of the renewable energy sector, no such study on growth and development of renewable energy enterprises has yet been conducted in Nepal. In this circumstance, the study deals with: Is the growth of biogas, solar and micro-hydro sector growing? Do the renewable energy sectors grow over the year and throughout the country? Do renewable energy enterprises grow significantly? Which sector's enterprises out of biogas companies, solar companies and micro-hydro construction companies have the largest growth over the year? Is there positive relationship between market size of renewable energy i.e., number of renewable energy systems' installation and renewable energy enterprises? Does growth and development of the renewable energy sector play an important role in growth and development of renewable energy enterprises in Nepal?

With the above backcloth, this study aims at determining the growth and development of renewable energy sector and its relationship with renewable energy enterprises (REEs) in Nepal. The remainder of the paper is organized as follows. Section 2 describes the data and methods employed in this study while section 3 analyzes the data collected for this study. Section 4 summarizes the results and offers some directions for future research. Finally, section 5 comprises acknowledgements of the study.

\section{METHOD}

Nepal has enormous potential for different kinds of renewable energies; however, pico/mini/micro-hydro, solar, biogas, wind and biomass energy are promoted as renewable 
ISSN: 2362-1303 (Paper) | eISSN: 2362-1311(Online)

JOURNAL OF ADVANCED ACADEMIC RESEARCH (JAAR)

energies in Nepal. Viewed in this perspective, biogas, solar and micro-hydro sectors have selected for this study.

The study comprises descriptive cum analytical research design based on secondary data. This study covers a period of 37 years of biogas sector, 20 years of solar sector and 50 years of micro-hydro sector as depicted in Table 1. The data and information are collected from Alternative Energy Promotion Centre (AEPC), Solar Electric Manufacturers' Association, Nepal (SEMAN), and Biogas Sector Partnership Nepal (BSP-Nepal), Kathmandu, Nepal. The key variables introduced in this study are the market size of renewable energy and renewable energy enterprises (REEs).

Table 1: Number of Observations Selected for the Study

\begin{tabular}{|cccc|}
\hline SN & Sectors & Years & Observations \\
\hline 1 & Biogas Sector & $1975 / 76$ to 2012/13 & 37 \\
\hline 2 & Solar Sector & $1992 / 93$ to 2012/13 & 20 \\
\hline 3 & Micro-hydro Sector & $1962 / 63$ to 2012/13 & 50 \\
\hline \multicolumn{2}{|c|}{ Total number of observations selected for the study } & $\mathbf{1 0 7}$ \\
\hline
\end{tabular}

Source: AEPC, SEMAN and BSP-Nepal.

There are 107 observations selected for the study out of 150 population observations ( 3 sectors x 50 years). Therefore, the percentage of selected observations is $\mathrm{n} / \mathrm{N}=107 / 150=71.33$ percent. This study is based on analysis of 107 observations for analyzing the relationship of the renewable energy sector with renewable energy enterprises (REEs). Moreover, the simple statistical techniques of analysis such as frequency table, percentage, graph, growth rate and correlation coefficient have been employed in this study using IBM SPSS Statistic 20.

\section{RESULTS}

In this section, an attempt is made to determine the growth and development of renewable energy sector and its relationship with renewable energy enterprises in Nepal. One of the important indicators of promotion of renewable energy enterprises is the number of construction companies working in the sector. The development of the market in the sector is indicated by its production both in terms in number and capacity.

\section{Biogas Sector}

The growth and development of the biogas sector is encouraging over the year based on its growth in its number and turnover. Despite of prolonged political transition, there is growth in 
ISSN: 2362-1303 (Paper) | eISSN: 2362-1311(Online)

JOURNAL OF ADVANCED ACADEMIC RESEARCH (JAAR) July 2015

biogas business that makes sense in developing biogas related enterprises in Nepal. Now, it may be interesting to analyze region-wise construction of biogas plants in Nepal. The biogas plants' construction by development regions till mid July 2013 is given in Table 2.

Table 2: Biogas Plants' Installation by Development Region from 1975/76 to 2012/13

\begin{tabular}{c|c|c|c|c|c|c|}
\hline \multicolumn{7}{c|}{ Development Region } \\
\cline { 2 - 7 } $\begin{array}{c}\text { Domestic } \\
\text { Biogas Plats }\end{array}$ & $\begin{array}{c}\text { Far Western } \\
(\boldsymbol{F W D R})\end{array}$ & $\begin{array}{c}\text { Mid Western } \\
(\boldsymbol{M W D R})\end{array}$ & $\begin{array}{c}\text { Western } \\
(\text { WDR })\end{array}$ & $\begin{array}{c}\text { Central } \\
(\boldsymbol{C D R})\end{array}$ & $\begin{array}{c}\text { Eastern } \\
(\text { EDR })\end{array}$ & Total \\
\hline Plants & 28,449 & 29,257 & 93,558 & 90,994 & 57,080 & $\mathbf{2 9 9 , 3 3 8}$ \\
\hline$\%$ & $9.50 \%$ & $9.77 \%$ & $31.25 \%$ & $30.40 \%$ & $19.07 \%$ & $\mathbf{1 0 0 \%}$ \\
\hline
\end{tabular}

Source: AEPC.

The biogas plants' construction by development region shows that the far-western and midwestern development regions have less than 10 percent number of plants constructed throughout the nation. However, the western and central development regions have more than 30 percent plants constructed. The eastern development region has about 19 percent plants constructed. There are the least number of plants constructed $(9.50$ percent) in far-western development region while it is the highest (31.25 percent) in western development region. Consequently, the development of the biogas sector is encouraging over the year and throughout the nation.

Likewise, it may be interesting to assess the growth of biogas sector in Nepal by periodic development plan. The growth and development of biogas sector by periodic development plan is given in Table 3.

Table 3: Biogas Plants' Installation by Periodic Development Plan of Nepal

\begin{tabular}{|c|c|c|c|c|c|c|c|c|c|c|}
\hline \multirow{2}{*}{$\begin{array}{c}\text { Domestic } \\
\text { Biogas } \\
\text { Plants }\end{array}$} & \multicolumn{8}{|c|}{ Periodic Development Plan of Nepal } & \multirow[b]{2}{*}{ Total } & \multirow[b]{2}{*}{ Mean } \\
\hline & $\begin{array}{c}\text { Till } 5^{\text {th }} \\
\text { Plan } \\
(1975-80)\end{array}$ & $\begin{array}{c}6^{\text {th }} \text { Plan } \\
(1980- \\
85)\end{array}$ & $\begin{array}{c}7^{\text {th }} \text { Plan } \\
(1985- \\
90)\end{array}$ & $\begin{array}{c}8^{\text {th }} \text { Plan } \\
(1992- \\
97)\end{array}$ & $\begin{array}{c}9^{\text {th }} \text { Plan } \\
\text { (1997- } \\
2002)\end{array}$ & $\begin{array}{c}10^{\text {th }} \text { Plan } \\
(2002- \\
07)\end{array}$ & $\begin{array}{l}11^{\text {th }} \text { Plan } \\
(2007 / 08- \\
2009 / 10)\end{array}$ & $\begin{array}{c}12^{\text {th }} \text { Plan } \\
(2010 / 11- \\
2012 / 13)\end{array}$ & & \\
\hline Plants & 799 & 1,090 & 6,939 & 27,485 & 67,570 & 79,183 & 55,521 & 60,751 & 299,338 & \\
\hline$\%$ & $0.27 \%$ & $0.36 \%$ & $2.32 \%$ & $9.18 \%$ & $22.57 \%$ & $26.45 \%$ & $18.55 \%$ & $20.30 \%$ & $100 \%$ & \\
\hline Growth in \% & & $36 \%$ & $537 \%$ & $296 \%$ & $146 \%$ & $17 \%$ & $-30 \%$ & $9 \%$ & & $145 \%$ \\
\hline
\end{tabular}

Vol. 2. No. II

www.phdcentre.edu.np 
ISSN: 2362-1303 (Paper) | eISSN: 2362-1311(Online)

JOURNAL OF ADVANCED ACADEMIC RESEARCH (JAAR)

July 2015

Source: AEPC.

The growth of biogas sector is increasing in decreasing trend from fifth to $12^{\text {th }}$ periodic development plan. However, the average growth rate is 145 percent. The constructed of biogas plants is less than one percent out of total in fifth and sixth plan and it is less three percent in seventh plan. However, it went up above nine percent in eighth plan and shows increasing trend afterward. It is due to the formal program on biogas sector called Biogas Support Program in Nepal started from 1992. The program makes sense in the sector and levered the sector. The data show that the largest number of plants (22.57 percent) constructed in $10^{\text {th }}$ plan whereas the least number of plants ( 0.27 percent) constructed in fifth plan and beforehand. Moreover, the number of biogas plants constructed in $9^{\text {th }}$ and $10^{\text {th }}$ plan is higher than that of $11^{\text {th }}$ and $12^{\text {th }}$ plan. The reason is that the $11^{\text {th }}$ and $12^{\text {th }}$ plan comprises only three years period while $9^{\text {th }}$ and $10^{\text {th }}$ plans have five years' time period. Consequently, it shows encouraging trend of the biogas sector that leads to grow and develop biogas companies in Nepal. There is growth in biogas business that makes sense in developing biogas related enterprises in Nepal.

\section{Solar Sector}

There is encouraging growth and development of the solar sector over the year both in term of number and turnover. Now, it may be interesting to analyze by development of region-wise installation of solar home systems in Nepal. The solar home systems' installation by development regions in Nepal till mid July 2013 is given in Table 4.

Table 4: Solar Home Systems' Installation by Development Region in Nepal till mid July 2013

\begin{tabular}{|c|c|c|c|c|c|c|c|}
\hline \multirow[b]{2}{*}{$\begin{array}{c}\text { Solar Home } \\
\text { Systems (SHS) }\end{array}$} & \multirow[b]{2}{*}{$\begin{array}{c}\text { Region } \\
\text { Unknown }\end{array}$} & \multicolumn{5}{|c|}{ Development Region } & \multirow[b]{2}{*}{ Total } \\
\hline & & $\begin{array}{c}\text { Far } \\
\text { Western } \\
(\text { FWDR })\end{array}$ & $\begin{array}{c}\text { Mid } \\
\text { Western } \\
(M W D R)\end{array}$ & $\begin{array}{c}\text { Western } \\
(\text { WDR })\end{array}$ & $\begin{array}{c}\text { Central } \\
(C D R)\end{array}$ & $\begin{array}{c}\text { Eastern } \\
(E D R)\end{array}$ & \\
\hline Number & 1,521 & 62,129 & 161,551 & 65,526 & 64,410 & 66,591 & 421,728 \\
\hline$\%$ & $0.36 \%$ & $14.73 \%$ & $38.31 \%$ & $15.54 \%$ & $15.27 \%$ & $15.79 \%$ & $100.00 \%$ \\
\hline Capacity (Wp) & 55,167 & $1,397,854$ & $3,407,138$ & $2,001,729$ & $1,665,942$ & $1,933,969$ & $10,461,799$ \\
\hline$\%$ & $0.53 \%$ & $13.36 \%$ & $32.57 \%$ & $19.13 \%$ & $15.92 \%$ & $18.49 \%$ & $100.00 \%$ \\
\hline
\end{tabular}

Source: AEPC. 
ISSN: 2362-1303 (Paper) | eISSN: 2362-1311(Online)

JOURNAL OF ADVANCED ACADEMIC RESEARCH (JAAR)

July 2015

The results on solar home systems' installation by development region show interesting facts about solar sector of Nepal. The largest number of solar systems is installed in mid-western development region of Nepal both in terms of number (38.31 percent) and in terms of capacity (32.57 percent) out of total systems installed in Nepal. Being the region with less served part of nation called Karnali Zone with different kind of development; the solar sector served this region at greater extent. Moreover, the far western development region has slightly lower number of solar systems installed than that of rest three regions (eastern, central and western). The eastern, central and western development region has almost equal number of systems installed till mid July 2013 both in terms of number and capacity. Consequently, the development of the solar sector is encouraging over the year.

Furthermore, it may be interesting to assess the growth of solar sector in Nepal by periodic development plan. The growth and development of solar sector by periodic development plan is given in Table 5.

Table 5: Solar Home Systems' Installation by Periodic Development Plan of Nepal

\begin{tabular}{|c|c|c|c|c|c|c|c|}
\hline $\begin{array}{c}\text { Solar Home } \\
\text { Systems (SHS) }\end{array}$ & $\begin{array}{c}8^{\text {th }} \text { Plan } \\
(1992-97)\end{array}$ & $\begin{array}{c}9^{\text {th }} \text { Plan } \\
(1997-2002)\end{array}$ & $\begin{array}{l}10^{\text {th }} \text { Plan } \\
(2002-07)\end{array}$ & $\begin{array}{c}11^{\text {th }} \text { Plan } \\
(2007 / 08- \\
2009 / 10)\end{array}$ & $\begin{array}{l}12^{\text {th }} \text { Plan } \\
(2010 / 11- \\
2012 / 13)\end{array}$ & Total & Mean \\
\hline SHS & 844 & 30,870 & 69,069 & 149,095 & 171,850 & 421,728 & \\
\hline$\%$ & $0.20 \%$ & $7.32 \%$ & $16.38 \%$ & $35.35 \%$ & $40.75 \%$ & $100 \%$ & \\
\hline Growth in \% & & $3558 \%$ & $124 \%$ & $116 \%$ & $15 \%$ & & $953 \%$ \\
\hline Capacity (Wp) & 30,090 & $1,198,112$ & $1,995,888$ & $3,424,609$ & $3,813,100$ & $10,461,799$ & \\
\hline$\%$ & $0.29 \%$ & $11.45 \%$ & $19.08 \%$ & $32.73 \%$ & $36.45 \%$ & $100 \%$ & \\
\hline Growth in \% & & $3882 \%$ & $67 \%$ & $72 \%$ & $11 \%$ & & $1008 \%$ \\
\hline
\end{tabular}

Source: AEPC.

The growth of solar home systems is increasing in decreasing trend from eighth plan to $12^{\text {th }}$ periodic development plan both in terms of number and capacity. The average growth of solar home systems and its capacity are 953 percent and 1008 percent respectively. The installation of systems is less than one percent out of total in eighth plan while it's grows up in ninth and tenth plan. It is due to the formal program on solar sector in Nepal started from 1996. The solar companies have grown up after this period. Consequently, an umbrella association of solar companies called Solar Electric Manufacturers' Association, Nepal (SEMAN) has established in 2000. Noticeably, there is the highest number of solar home systems installed in terms of number (40.75 percent) and its capacity (36.45 percent) during $12^{\text {th }}$ periodic development plan of Nepal. Despite of prolonged political transition, it is a major turn in development of solar sector in Nepal. 
ISSN: 2362-1303 (Paper) | eISSN: 2362-1311(Online)

JOURNAL OF ADVANCED ACADEMIC RESEARCH (JAAR)

July 2015

\section{Micro-hydro Sector}

The micro-hydro sector is encouraging both in term of number and turnover. Now, it may be interesting to analyze the region-wise micro-hydro electrification schemes' installation in Nepal as given in Table 6 .

Table 6 shows the far-western development region has the least number of micro-hydro electrification schemes' installation (6.01 percent) while the eastern development region has the largest number of schemes' installation (35.17 percent) till mid July 2013. In term of capacity, the mid-western development region has the least capacity (11.14 percent) installed whereas it is highest (28.43 percent) in western region. Consequently, the development of the micro-hydro sector is encouraging throughout the country over the year.

Table 6: Micro-hydro Electrification Schemes' Installation by Development Region in Nepal from 1962 to Mid July 2013

\begin{tabular}{|c|c|c|c|c|c|c|c|}
\hline \multirow{2}{*}{$\begin{array}{c}\text { Micro-hydro } \\
\text { Electrification } \\
\text { Schemes }\end{array}$} & $\begin{array}{c}\text { Region } \\
\text { Unknown }\end{array}$ & $\begin{array}{c}\text { Far } \\
\text { Western } \\
(\boldsymbol{F W D R})\end{array}$ & $\begin{array}{c}\text { Mid Western } \\
(\boldsymbol{M W D R})\end{array}$ & $\begin{array}{c}\text { Western } \\
(\text { WDR })\end{array}$ & $\begin{array}{c}\text { Central } \\
(\boldsymbol{C D R})\end{array}$ & $\begin{array}{c}\text { Eastern } \\
(\text { EDR })\end{array}$ & \multirow{2}{*}{ Total } \\
\hline Number & 288 & 186 & 242 & 735 & 556 & 1,089 & $\mathbf{3 , 0 9 6}$ \\
\hline$\%$ & $9.30 \%$ & $6.01 \%$ & $7.82 \%$ & $23.74 \%$ & $17.96 \%$ & $35.17 \%$ & $100 \%$ \\
\hline Capacity (KW) & 5,153 & 5,332 & 4,582 & 13,615 & 7,639 & 11,564 & $\mathbf{4 7 , 8 8 4}$ \\
\hline$\%$ & $10.76 \%$ & $11.14 \%$ & $9.57 \%$ & $28.43 \%$ & $15.95 \%$ & $24.15 \%$ & $100 \%$ \\
\hline
\end{tabular}

Source: AEPC.

Furthermore, it may be interesting to assess the growth and development of micro-hydro sector in Nepal by periodic development plan. The growth and development of micro-hydro sector by periodic development plan is given in Table 7.

Table 7: Micro-hydro Electrification Schemes' Installation by Periodic Plan of Nepal

\begin{tabular}{|c|c|c|c|c|c|c|c|c|c|c|}
\hline \multirow{2}{*}{$\begin{array}{l}\text { Micro-hydro } \\
\text { Electrification } \\
\text { Schemes }\end{array}$} & \multirow[b]{2}{*}{$\begin{array}{c}\text { Year } \\
\text { Unknown }\end{array}$} & \multicolumn{7}{|c|}{ Periodic Development Plan of Nepal } & \multirow[t]{2}{*}{ Total } & \multirow[b]{2}{*}{ Mean } \\
\hline & & $\begin{array}{c}\text { Till }^{\text {th }} \\
\text { Plan } \\
(1980- \\
85)\end{array}$ & $\begin{array}{c}7^{\text {th }} \\
\text { Plan } \\
(1985- \\
90)\end{array}$ & $\begin{array}{c}8^{\text {th }} \\
\text { Plan } \\
\text { (1992- } \\
97)\end{array}$ & $\begin{array}{c}9^{\text {th }} \\
\text { Plan } \\
\text { (1997- } \\
2002)\end{array}$ & $\begin{array}{c}10^{\text {th }} \\
\text { Plan } \\
(2002- \\
07)\end{array}$ & $\begin{array}{l}11^{\text {th }} \text { Plan } \\
(2007 / 08- \\
2009 / 10)\end{array}$ & $\begin{array}{l}12^{\text {th }} \text { Plan } \\
(2010 / 11- \\
2012 / 13)\end{array}$ & & \\
\hline Number & 287 & 68 & 148 & 459 & 606 & 576 & 391 & 561 & 3,096 & \\
\hline$\%$ & $9.27 \%$ & $2.20 \%$ & $4.78 \%$ & $14.83 \%$ & $19.57 \%$ & $18.60 \%$ & $12.63 \%$ & $18.12 \%$ & $100 \%$ & \\
\hline Growth in \% & & & $118 \%$ & $210 \%$ & $32 \%$ & $-5 \%$ & $-32 \%$ & $43 \%$ & & $61 \%$ \\
\hline Capacity(KW) & 17,419 & 593 & 1,072 & 1,352 & 3,639 & 5,333 & 5,553 & 12,923 & 47,884 & \\
\hline$\%$ & $36.38 \%$ & $1.24 \%$ & $2.24 \%$ & $2.82 \%$ & $7.60 \%$ & $11.14 \%$ & $11.60 \%$ & $26.99 \%$ & $100 \%$ & \\
\hline Growth in \% & & & $81 \%$ & $26 \%$ & $169 \%$ & $47 \%$ & $4 \%$ & $133 \%$ & & $77 \%$ \\
\hline
\end{tabular}

Vol. 2. No. II

www.phdcentre.edu.np 
ISSN: 2362-1303 (Paper) | eISSN: 2362-1311(Online)

JOURNAL OF ADVANCED ACADEMIC RESEARCH (JAAR)

Source: AEPC.

Note: The schemes constructed in year 1991 has included under 7th plan.

The growth of micro-hydro sector has ups-down trend from sixth plan to $12^{\text {th }}$ periodic development plan both in terms of number and capacity. The average growth in terms of number and its capacity are 61 percent and 77 percent respectively. The sixth plan has the least number of micro-hydro schemes' installation both in term of number and capacity. The ninth plan has the largest number of schemes' installation while $12^{\text {th }}$ plan has the largest number schemes in term of capacity.

\section{Renewable Energy Enterprises (REEs)}

Renewable energy enterprises (REEs) comprising biogas companies, solar companies and micro-hydro construction companies are one of the important indicators of enterprise development in the renewable energy sector. Moreover, the trend of renewable energy enterprises in Nepal is given in Figure 1.

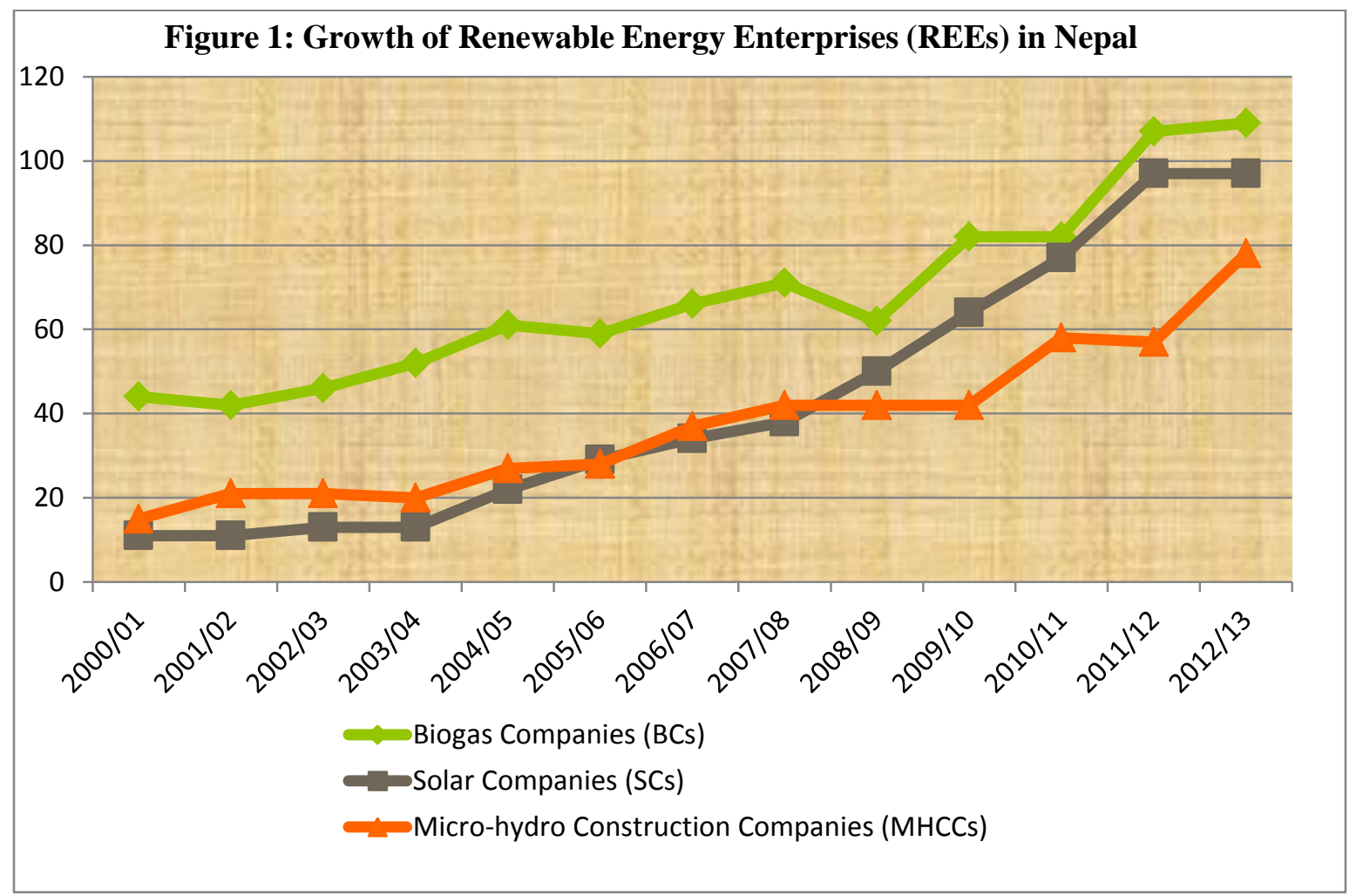

Source: AEPC.

The trend of biogas companies, solar companies and micro-hydro companies are in increasing trend over the year. The results show that the market of renewable energy enterprises has been growing during past decade. Furthermore, it may be interesting to assess the region-wise Vol. 2. No. II www.phdcentre.edu.np 
ISSN: 2362-1303 (Paper) | eISSN: 2362-1311(Online)

JOURNAL OF ADVANCED ACADEMIC RESEARCH (JAAR) July 2015

presence of renewable energy enterprises in Nepal. Table 8 shows that the market size of renewable energy is growing throughout the nation.

There is high concentration of the renewable energy enterprises in central development region (62.69 percent) while the least concentration of the REEs is in far-western development region (3.08 percent) of Nepal. This might be due take centralized infrastructure and services in Kathmandu, the capital city of Nepal.

Table 8: Region-wise Number of Renewable Energy Enterprises (REEs) in Nepal

\begin{tabular}{|c|c|c|c|c|c|c|c|}
\hline \multirow[b]{2}{*}{ SN } & \multirow[b]{2}{*}{ REEs } & \multicolumn{5}{|c|}{ Development Regions } & \multirow[b]{2}{*}{ Total } \\
\hline & & Eastern & Central & Western & $\begin{array}{c}\text { Mid- } \\
\text { Western }\end{array}$ & $\begin{array}{c}\text { For- } \\
\text { Western }\end{array}$ & \\
\hline 1 & Biogas Companies & 21 & 46 & 25 & 15 & 6 & 113 \\
\hline 2 & Solar Companies & 1 & 62 & 1 & 4 & 1 & 69 \\
\hline 3 & Micro-hydro Construction Companies & 2 & 55 & 19 & 1 & 1 & 78 \\
\hline & Total & 24 & 163 & 45 & 20 & 8 & 260 \\
\hline & $\%$ & $9.23 \%$ & $62.69 \%$ & $17.31 \%$ & $7.69 \%$ & $3.08 \%$ & $100 \%$ \\
\hline
\end{tabular}

Sources: Web Page of AEPC as of $5^{\text {th }}$ August 2014: www.aepc.gov.np.

Furthermore, there were 44 biogas companies in fiscal year 2000/01 while it went up to 109 biogas companies in fiscal year 2012/13. There were only 11 solar companies working in the sector in fiscal year 2000/01. However, it reached 97 solar companies in fiscal year 2012/13. Likewise, the micro-hydro construction companies went up to 78 companies in 2012/13 from 15 companies in fiscal year 2000/01. Based on increase in renewable energy enterprises (REEs), increase in number and capacity of systems installed, the sector has been grown considerably that leads to entrepreneurship development.

Now, it may be interesting the see growth rate of renewable energy enterprises in Nepal. Table 9 shows encouraging growth rate of REEs in Nepal.

Table 9: Growth of Renewable Energy Enterprises in Nepal

\begin{tabular}{|c|c|c|c|c|c|c|}
\hline Fiscal Year & $\begin{array}{c}\text { Biogas } \\
\text { Companies } \\
\text { (BCs) }\end{array}$ & $\begin{array}{c}\text { Growth of } \\
\text { BCs (\%) }\end{array}$ & $\begin{array}{c}\text { Solar } \\
\text { Companies } \\
\text { (SCs) }\end{array}$ & $\begin{array}{l}\text { Growth of } \\
\text { SCs }(\%)\end{array}$ & $\begin{array}{c}\text { Micro-hydro } \\
\text { Construction } \\
\text { Companies (MHCCs) }\end{array}$ & $\begin{array}{c}\text { Growth of } \\
\text { MHCCs }(\%)\end{array}$ \\
\hline $2000 / 01$ & 44 & & 11 & & 15 & \\
\hline $2001 / 02$ & 42 & $-4.55 \%$ & 11 & $0.00 \%$ & 21 & $40.00 \%$ \\
\hline $2002 / 03$ & 46 & $9.52 \%$ & 13 & $18.18 \%$ & 21 & $0.00 \%$ \\
\hline $2003 / 04$ & 52 & $13.04 \%$ & 13 & $0.00 \%$ & 20 & $-4.76 \%$ \\
\hline $2004 / 05$ & 61 & $17.31 \%$ & 22 & $69.23 \%$ & 27 & $35.00 \%$ \\
\hline $2005 / 06$ & 59 & $-3.28 \%$ & 29 & $31.82 \%$ & 28 & $3.70 \%$ \\
\hline $2006 / 07$ & 66 & $11.86 \%$ & 34 & $17.24 \%$ & 37 & $32.14 \%$ \\
\hline $2007 / 08$ & 71 & $7.58 \%$ & 38 & $11.76 \%$ & 42 & $13.51 \%$ \\
\hline $2008 / 09$ & 62 & $-12.68 \%$ & 50 & $31.58 \%$ & 42 & $0.00 \%$ \\
\hline $2009 / 10$ & 82 & $32.26 \%$ & 64 & $28.00 \%$ & 42 & $0.00 \%$ \\
\hline $2010 / 11$ & 82 & $0.00 \%$ & 77 & $20.31 \%$ & 58 & $38.10 \%$ \\
\hline
\end{tabular}

Vol. 2. No. II

www.phdcentre.edu.np 
ISSN: 2362-1303 (Paper) | eISSN: 2362-1311(Online)

JOURNAL OF ADVANCED ACADEMIC RESEARCH (JAAR)

\begin{tabular}{|c|c|c|c|c|c|c|}
\hline 2011/12 & 107 & $30.49 \%$ & 97 & $25.97 \%$ & 57 & $-1.72 \%$ \\
\hline $2012 / 13$ & 109 & $1.87 \%$ & 97 & $0.00 \%$ & 78 & $36.84 \%$ \\
\hline & Mean & $7.96 \%$ & & $21.18 \%$ & & $16.07 \%$ \\
\hline
\end{tabular}

Source: AEPC, BSP-Nepal and SEMAN.

The growth rate of biogas companies, solar companies and micro-hydro construction companies are non-linear over the year. The average growth rate of biogas companies, solar companies and micro-hydro construction companies are 7.96 percent, 21.18 percent and 16.07 percent respectively. The average growth rate of solar companies is the highest while it is the lowest in case of biogas companies. The growth rate of REEs is encouraging and compactable with the growth rate of the sector.

Table 10 shows the correlation among the variables. The correlation coefficients are significant in all cases. The correlation coefficient ( $r$ ) between total biogas plants and biogas companies is 0.88. There is very high degree of positive correlation between them. The total plants and number of biogas companies move in the same direction. The correlation coefficient (r) between total solar home systems and solar companies is 0.82 . There is very high degree of positive correlation between them. The total solar home systems and solar companies move in the same direction.

Table 10: Correlation of market Size of Renewable Energy with REEs

\begin{tabular}{|c|c|c|c|}
\hline SN & Particulars & Correlation, $\mathbf{r}$ & Sig. (2-tailed) \\
\hline $\mathbf{1}$ & $\begin{array}{c}\text { Correlation between total biogas plants (P) and biogas } \\
\text { companies (BCs), rPBCs }\end{array}$ & $0.88^{* *}$ & 0.000 \\
\hline $\mathbf{2}$ & $\begin{array}{c}\text { Correlation between total solar home systems (SHS) and } \\
\text { solar companies (SCs), rSHSSCs }\end{array}$ & $0.82^{* *}$ & 0.001 \\
\hline $\mathbf{3}$ & $\begin{array}{c}\text { Correlation between total micro-hydro electrification } \\
\text { schemes (MHS) and micro-hydro construction companies } \\
(\mathrm{MHCCs}), \text { rMHSMHCCs }\end{array}$ & $0.59^{*}$ & 0.032 \\
\hline
\end{tabular}

Source: AEPC.

Note: $* *$ and $*$ indicate the correlation coefficient are significant at the 0.01 level (2-tailed) and at the 0.05 level (2-tailed) respectively.

Likewise, the correlation coefficient (r) between total micro-hydro electrification schemes and micro-hydro construction companies is 0.59 . There is high degree of positive correlation between them. The total micro-hydro electrification schemes and micro-hydro construction companies move in the same direction. If market size of renewable energy increase then the REEs also increases and vice versa. 
ISSN: 2362-1303 (Paper) | eISSN: 2362-1311(Online)

JOURNAL OF ADVANCED ACADEMIC RESEARCH (JAAR)

July 2015

\section{CONCLUSIONS}

The results of this study lead to the important findings. There is high penetration of biogas plants (31.25 percent) in western development region. The largest number of solar systems is installed in less served part of nation called mid-western development region both in terms of number (38.31 percent) and capacity (32.57 percent). The eastern development region has the largest number of micro-hydro schemes' installation (35.17 percent) in term of number while it is the highest (28.43 percent) in western development region in term of capacity. The growth of the market of biogas and solar sectors are increasing in decreasing trend over the periodic development plan of Nepal while it is ups-down trend in case of micro hydro sector. Likewise, there is high concentration of the renewable energy enterprises (REEs) in central development region (62.69 percent) while the least concentration is in far-western region (3.08 percent) of Nepal. The average growth rate of biogas companies, solar companies and micro-hydro construction companies are 7.96 percent, 21.18 percent and 16.07 percent respectively. The average growth rate of solar companies is the highest while it is the lowest in case of biogas companies. Moreover, the correlation coefficient (r) between biogas plants and biogas companies is 0.88 . The correlation coefficient (r) between solar home systems and solar companies is 0.82 . Likewise, the correlation coefficient (r) between micro-hydro electrification schemes and micro-hydro construction companies is 0.59 . There is very high degree of positive correlation in case of biogas and solar while it is high degree of positive correlation in case of micro-hydro sector. The correlation coefficients are significant in all cases.

The results of this study lead to the important conclusions. The study reveals that the growth and development of renewable energy sector is encouraging over the year and throughout the country. The growth of renewable energy enterprises are encouraging and largely located in central region but serve western and mid-western development region at greater extent. There is significant positive relationship of market size of renewable energy i.e., number of renewable energy systems' installation with renewable energy enterprises. Consequently, the growth and development of the renewable energy sector plays a vital role in growth and development of renewable energy enterprises in Nepal. The results show diverse growth rate and ups-down trend over the years. In order to find out the reasons, the paper can be extended through investigating the characteristics of renewable energy enterprises and renewable energy entrepreneurs to get a greater insight into the results.

\section{ACKNOWLEDGEMENTS}

We appreciatively acknowledge the cooperation received in collecting data from AEPC, BSPNepal and SEMAN as well as all writers and researchers whose write up used as references for this study. We would also like to express our sincere thanks to Prof. Dr. Tatwa P. Timsina and Mr. Tej Bahadur Karki and other team members of $\mathrm{PhD}$ Centre, Kathmandu for expected encouragement. Last but not least, we are also indebted to the Southwestern Centre for PhD Vol. 2. No. II 
ISSN: 2362-1303 (Paper) | eISSN: 2362-1311(Online)

JOURNAL OF ADVANCED ACADEMIC RESEARCH (JAAR)

July 2015

Studies for providing an opportunity to publish this article in its Journal of Advanced Academic Research (JAAR).

\section{REFERENCES}

Adhikary, D. K. (2012, August ). Green Economy: In Pursuance of Sustainable Development. Administrative and Management Review, 24(2), 77-89.

AEPC. (2012). Annual Progress Report 2010/11. Kathmandu: Alternative Energy Promotion Center, Ministry of Environment, Science and Technology.

AEPC. (2013). NRREP Baseline Part B: Baseline of Renewable Energy Technology Installations in Nepal. Kathmandu: Alternative Energy Promotion Centre (AEPC).

AEPC. (2014). Alternative Energy Promotion Centre (AEPC). Retrieved August 25, 2014, from http://www.aepc.gov.np

Arthur, R., Baidoo, M. F., \& Antwi, E. (2011). Biogas as a potential renewable energy source: A Ghanaian case study. (A. A. Sayigh, Ed.) Renewable Energy, 36(5), 1510-1516.

Goldemberg, J. (1996). Energy, Environment and Development. U.K.: Earthscan.

International Energy Agency. (2011). Solar Energy Perspectives: Executive Summary. International Energy Agency.

Karki, A. B., Shrestha, J. N., Bajgain, S., \& Sharma, I. (2009). Biogas as Renewable Source of Energy in Nepal: Theory and Development. Kathmandu: BSP-Nepal.

Pokharel, G. R. (2006). Promoting Sustainable Development by Creating Enterprises on Renewable Energy Technologies in Nepal: Case Studies Based on Micro Hydropower Projects . Germany: Institut für Politik und Wirtschaft und Ihre Didaktik.

USAID SARI. (2012, July 15). Energy sector in Nepal. Retrieved from http://www.sarienergy.org/PageFiles/Countries/Nepal_Energy_detail.asp

White, R. A. (2005). The Role of Biogas in Rural Development and Resource Protection in China: A Case Study of Lijiang Municipality. Yunnan: National Science Foundation and Michigan State University.

Wikipedia: 28 Feb 2013. (n.d.). Retrieved February 28, 2013, from Wikipedia Web site: http://en.wikipedia.org

World Commission on Environment and Development. (1987). Our Common Future. U.K.: Oxford University Press.

Yadav, M. P. (2011, Oct-Dec ). Role of Key Factors for Biogas Development: A Case of Nepal. The Economic Journal of Nepal, 34(136), 310-318.

Yadav, M. P. (2014b). Biogas for Sustainable Development: Users' Perspective (1st ed.). Germany: LAMBERT Academic Publishing.

Vol. 2. No. II

www.phdcentre.edu.np 
ISSN: 2362-1303 (Paper) | eISSN: 2362-1311(Online)

JOURNAL OF ADVANCED ACADEMIC RESEARCH (JAAR) July 2015

Yadav, M. P. (2015). Key Factors of Enterprise Development: Evidence from Solar Sector of Nepal. International Conference on Economics and Finance. Kathmandu: Nepal Rastra Bank. 